\title{
Prinsip Persiapan Penempatan dan Perlindungan Tenaga Kerja Indonesia di Luar Negeri
}

\author{
Suhartoyo \\ Fakultas Hukum, Universitas Diponegoro \\ suhartoyo@live.undip.ac.id
}

\begin{abstract}
This study aims to determine the principle of placement and protection of Indonesian workers in the country. This research is a normative legal research which is analyzed using qualitative analysis. The results showed that the Principle of Placement and Protection of Indonesian Workers Abroad is to place and protect Indonesian Workers abroad, i.e. a). Original but fake identity documents are socialized about the importance of the truth about identity data because this is very helpful and facilitates the management of various kinds of problems. In addition, a continuous review, evaluation and supervision of the completeness of the TKI's personal data are also carried out. The most important thing to do is sanctions and decisive action for those who have genuine but fake identity documents. b). Training Certificate, Health Test Certificate, False Competency Test Certificate. Urge relevant parties not to help pass migrant workers who do not meet graduation requirements in training, health testing, and competency tests to obtain falsified certificates. c). Employers who do not meet work agreements / wages are not paid. Faced with this matter, it will be submitted to the authorities who handle this so that this problem can be resolved properly, namely the TKI receives his right to receive wage payments from the work of TKI with a specified amount of money.
\end{abstract}

Keywords: Principles, Placement of Indonesian Workers, Overseas, Labor

\begin{abstract}
Abstrak
Penelitian ini bertujuan untuk mengetahui prinsip penempatan dan perlindungan tenaga kerja indonesia di laur negeri. Penelitian ini adalah penelitian hukum normatif yang dianalisi menggunakan analisis kualitatif. Hasil penelitian menunjukan bahwa Prinsip Penempatan dan Perlindungan Tenaga Kerja Indonesia di Luar Negeri adalah dengan melakukan penempatan dan perlindungan Tenaga Kerja Indonesia di luar negeri yaitu a). Dokumen jati diri asli tetapi palsu disosialisaikan tentang pentingnya kebenaran tentang data jati diri karena hal ini sangat membantu dan memudahkan pengurusan berbagai macam masalah. Selain itu juga terus menerus dilakukan peninjauan ulang, mengevaluasi, dan mengawasi kelengkapan data-data diri para TKI. Hal yang paling penting dilakukan adalah sanksi dan tindakan tegas bagi mereka yang memiliki dokumen jati diri asli tetapi palsu. b). Sertifikat Pelatihan, Sertifikat Uji Kesehatan, Sertifikat Uji Kompetensi yang dipalsukan. Menghimbau agar pihak yang terkait tidak membantu meloloskan TKI yang tidak memenuhi syarat kelulusan dalam pelatihan, uji kesehatan, dan uji kompetensi untuk memperoleh sertifikan yang dipalsukan. c). Majikan yang tidak memenuhi perjanjian kerja/upah tidak dibayar. Menghadapi hal ini maka akan diajukan kepada pihak yang berwenang yang menangani hal ini sehingga masalah ini dapat terselesaikan dengan baik yaitu TKI menerima haknya untuk menerima pembayaran upah dari hasil kerja TKI dengan sejumlah uang yang besarannya telah ditentukan.
\end{abstract}

Kata Kunci: Prinsip, Penempatan Tenaga Kerja Indonesia, Luar Negeri, Ketenagakerjaan 


\section{A. Pendahuluan}

Setiap warga negara pada dasarnya memiliki keinginan untuk hidup dan bekerja secara layak agar mendapatkan kehidupan yang sejahtera, karena kehidupan sejahtera adalah hak bagi setiap warga. Setiap hak berawal dengan kewajiban maka dari itu setiap warga memiliki kewajiban untuk mencapai kehidupan yang sejahtera. Dengan kata lain kehidupan sejahtera dicapai apabila setiap warga menerima hak dan memenuhi kewajibannya sebagai warga negara dan sebagai tenaga kerja. Pemerintah sebagai penguasa yang memegang peranan penting, dalam pencapaian kehidupan yang sejahtera dan memiliki andil besar dalam mengatur serta mencanangkan program-program pendukung agar tercapainya kehidupan masyarakat yang sejahtera dan terpenuhinya lapangan kerja. Pemerintah dan masyarakat memiliki kesinambungan yang amat sulit untuk dipisahkan, pemerintah berkewajiban meyediakan peluang dan lapangan kerja sedangkan masyarakat harus memenuhi syarat dan kewajiban sebagai tenaga kerja. Oleh karena itu UUD 1945 menekankan pentingnya kehidupan sejahtera, dan kesanggupan pemerintah memberikan lapangan kerja yang dikehendaki.

Masalah ketenagakerjaan Indonesia dari tahun ke tahun dihadapkan pada pertumbuhan angkatan kerja yang tinggi di satu sisi, sementara di sisi lain tingkat pendidikan dan keahlian yang masih belum memadai dan lapangan kerja yang terbatas. Pemerintah berusaha untuk mengurangi angka pengangguran dan juga meningkatkan kualitas hidup tenaga kerja di Indonesia. Oleh karena itu penempatan tenaga kerja ke luar negeri merupakan salah satu alternatif pilihan dalam menyelesaikan masalah tersebut.

Ketenagakerjaan berasal dari kata tenaga kerja, yang dalam Pasal 1 angka 2 UU No. 13 Tahun 2003 tentang Ketenagakerjaan disebutkan bahwa Tenaga kerja adalah setiap orang yang mampu melakukan pekerjaan guna menghasilkan barang dan/atau jasa baik untuk memenuhi kebutuhan sendiri maupun untuk masyarakat. Sedangkan pengertian dari ketenagakerjaan sesuai dengan Pasal 1 angka 1 UU No. 13 Tahun 2003 tentang Ketenagakerjaan adalah segala hal yang berhubungan dengan tenaga kerja pada waktu sebelum, selama, dan sesudah masa kerja. Dalam Pasal 31 Undang-Undang Nomor 13 Tahun 2003 dinyatakan bahwa setiap tenaga kerja mempunyai hak dan kesempatan yang sama untuk memilih, mendapatkan, atau pindah pekerjaan dan memperoleh penghasilan yang layak di dalam atau di luar negeri. Kemudian dalam pasal 32 ayat (1) dan ayat (2) dijelaskan bahwa penempatan tenaga kerja dilaksanakan berdasarkan asas terbuka, bebas, obyektif, serta adil, dan setara tanpa diskriminasi. Penempatan tenaga kerja diarahkan 
untuk menempatkan tenaga kerja pada jabatan yang tepat sesuai dengan keahlian, keterampilan, bakat, minat, dan kemampuan dengan memperhatikan harkat, martabat, hak asasi, dan perlindungan hukum ${ }^{1}$.

Pasal 33 UU No.13 Tahun 2003 menentukan penempatan tenaga kerja yang terdiri dari penempatan tenaga kerja di dalam negeri dan penempatan tenaga kerja di luar negeri. Berkenaan dengan penempatan tenaga kerja di luar negeri, secara terperinci lebih lanjut diatur dalam Undang-Undang Nomor 39 Tahun 2004 tentang Penempatan dan Perlindungan Tenaga Kerja Indonesia di Luar Negeri.Dengan disahkannya Undangundang tersebut, seharusnya semakin jelas dan nyata kewenangan pemerintah pusat dan pemerintah daerah dalam mengatur penempatan TKI.

Pasal 1 angka 1 Undang-Undang Nomor 39 Tahun 2004 memberikan definisi yuridis Tenaga Kerja Indonesia yang selanjutnya disebut dengan TKI adalah setiap warga negara Indonesia yang memenuhi syarat untuk bekerja di luar negeri dalam hubungan kerja untuk jangka waktu tertentu dengan menerima upah. Sedangkan dalam pasal 1 angka 3 dalam Undang-Undang Nomor 39 Tahun 2004 bahwa yang dimaksud dengan penempatan TKI adalah kegiatan pelayanan untuk mempertemukan TKI sesuai bakat, minat, dan kemampuannya dengan pemberi kerja di luar negeri yang meliputi keseluruhan proses perekrutan, pengurusan dokumen, pendidikan dan pelatihan, penampungan, persiapan pemberangkatan, pemberangkatan sampai ke negara tujuan, dan pemulangan dari negara tujuan.

Undang-Undang Nomor 13 tahun 2003 tentang Ketenagakerjaan pada Pasal 31 sampai dengan Pasal 38 mengatur masalah penempatan tenaga kerja. Dalam Pasal 31 Undang-Undang tersebut dinyatakan bahwa setiap tenaga kerja mempunyai hak dan kesempatan yang sama untuk memilih, mendapatkan, atau pindah pekerjaan dan memperoleh penghasilan yang layak di dalam atau di luar negeri. Undang-Undang Ketenagakerjaan Pasal 33 tersebut mengatur bahwa penempatan tenaga kerja terdiri dari penempatan tenaga kerja di dalam negeri dan penempatan tenaga kerja di luar negeri. Selanjutnya Undang-Undang Ketenagakerjaan Pasal 34 mengamanatkan bahwa Ketentuan mengenai penempatan tenaga kerja di luar negeri harus diatur dengan undang-undang tersendiri.

Penempatan Tenaga Kerja Indonesia ke Luar Negeri diatur dalam Undang-Undang No. 39 Tahun 2004 tentang Penempatan dan Perlindungan Tenaga Kerja Indonesia di Luar Negeri. Namun demikian, ketika dibaca dan ditelaah secara kritis, Undang-Undang ini ternyata lebih banyak mengatur prosedural dan tata cara penempatan TKI ke luar negeri, 
dan hanya sedikit mengatur jaminan perlindungan hak-hak TKI dan anggota keluarganya. Dalam Pasal 1 angka (1) Undang-Undang Nomor 39 tahun 2004 disebutkan bahwa yang dimaksud dengan Tenaga Kerja Indonesia yang selanjutnya disebut dengan TKI adalah setiap warga negara Indonesia yang memenuhi syarat untuk bekerja di luar negeri dalam hubungan kerja untuk jangka waktu tertentu dengan menerima upah. Pada konsiderans Undang-Undang tersebut pada huruf c disebutkan bahwa setiap tenaga kerja mempunyai hak dan kesempatan yang sama tanpa diskriminasi untuk memperoleh pekerjaan dan penghasilan yang layak baik di dalam maupun di luar negeri sesuai dengan keahlian, keterampilan, bakat, minat dan kemampuan. Dalam kenyataan yang terjadi, tenaga kerja Indonesia yang bekerja di luar negeri menghadapi berbagai persoalan, antara lain menjadi obyek perdagangan manusia, termasuk perbudakan dan kerja paksa, korban kekerasan, kesewenangwenangan, kejahatan atas harkat dan martabat manusia serta perlakuan lain yang melanggar hak asasi manusia. Oleh karena itu negara wajib menjamin dan melindungi hak asasi warga negaranya yang bekerja baik di dalam maupun di luar negeri berdasarkan prinsip persamaan hak, demokrasi, keadilan sosial, kesetaraan dan keadilan gender, anti diskriminasi dan anti perdagangan manusia ${ }^{1}$.

Kebijakan penempatan tenaga kerja Indonesia di luar negeri merupakan suatu upaya untuk mewujudkan hak dan kesempatan yang sama bagi tenaga kerja untuk memperoleh pekerjaan dan penghasilan yang layak, yang pelaksanaannya dilakukan dengan tetap memperhatikan harkat, martabat, hak asasi manusia dan perlindungan hukum serta pemerataan kesempatan kerja dan penyedian tenaga kerja yang sesuai dengan kebutuhan nasional. Hal ini sebagaimana diatur dalam Pasal 1 angka 3 dalam Undang-Undang Nomor 39 tahun 2004. Penempatan TKI adalah kegiatan pelayanan untuk mempertemukan TKI sesuai bakat, minat, dan kemampuannya dengan pemberi kerja di luar negeri yang meliputi keseluruhan proses perekrutan, pengurusan dokumen, pendidikan dan pelatihan, penampungan, persiapan pemberangkatan, pemberangkatan sampai ke negara tujuan, dan pemulangan dari negara tujuan.

Dalam berbagai dokumen perencanaan pembangunan, kebijakan penempatan TKI ke luar negeri, merupakan program nasional sebagai upaya meningkatkan kesejahteraan tenaga kerja dan keluarganya serta pengembangan kualitas sumber daya manusia. Penempatan TKI dilakukan dengan memanfaatkan pasar kerja internasional melalui peningkatan kualitas kompetensi tenaga kerja dengan perlindungan yang optimal sejak

\footnotetext{
${ }^{1}$ Muslan Abdurrahman, 2006, Ketidakpatuhan TKI Sebuah Efek Diskriminasi Hukum. Malang, PT. Penerbitan Universitas Muhammadiyah Malang, hlm.31
} 
sebelum keberangkatan, selama bekerja di luar negeri sampai tiba kembali di Indonesia. Perlindungan menurut Penjelasan Umum UU No. 13 Tahun 2003 tentang Ketenagakerjaan mencakup berbagai aspek kehidupan masyarakat yang seharusnya bersubsidi pada kekuasaan rakyat sehingga hukum harus tetap mengedepankan keadilan, tidak lagi hanya berorientasi pada kepentingan penguasa atau kepentingan politik. Apabila hukum tetap hanya berorientasi pada kepentingan politik atau penguasa maka kepentingan rakyat untuk mendapat perlindungan akan terabaikan.

Penyelenggaraan perlindungan, pemeliharaan dan peningkatan kesejahteraan merupakan salah satu tanggung jawab dan kewajiban negara. Demikian pula UU No. 13 Tahun 2003 yang mengatur mengenai perlindungan terhadap TKI. Akan tetapi dalam pelaksanaannya masih banyak persoalan-persoalan yang perlu diselesaikan. Hal ini juga dialami oleh oleh tenaga kerja Indonesia yang bekerja di luar negeri. Undang-Undang No. 39 Tahun 2004 tentang Penempatan dan Perlindungan TKI di Luar Negeri, dalam implementasinya belum menyentuh pada cakupan perlindungan yang memadai pada tenaga kerja Indonesia yang bekerja di luar negeri.

Pasal 32 ayat (1) dan ayat (2) menjelaskan bahwa Penempatan tenaga kerja dilaksanakan berdasarkan asas terbuka, bebas, obyektif, serta adil, dan setara tanpa diskriminasi. Penempatan tenaga kerja diarahkan untuk menempatkan tenaga kerja pada jabatan yang tepat sesuai dengan keahlian, keterampilan, bakat, minat, dan kemampuan dengan memperhatikan harkat, martabat, hak asasi, dan perlindungan hukum. Dalam berbagai dokumen perencanaan pembangunan, kebijakan penempatan TKI ke luar negeri, merupakan program nasional dalam upaya meningkatkan kesejahteraan tenaga kerja dan keluarganya serta pengembangan kualitas sumber daya manusia. Penempatan TKI dilakukan dengan memanfaatkan pasar kerja internasional melalui peningkatan kualitas kompetensi tenaga kerja dengan perlindungan yang optimal sejak sebelum keberangkatan, selama bekerja di luar negeri sampai tiba kembali di Indonesia.

Perlindungan menurut Penjelasan Umum UU No. 13 Tahun 2003 tentang Ketenagakerjaan mencakup berbagai aspek kehidupan masyarakat yang seharusnya bersubsidi pada kekuasaan rakyat sehingga hukum harus tetap mengedepankan keadilan, tidak lagi hanya berorientasi pada kepentingan penguasa atau kepentingan politik. Apabila hukum tetap hanya berorientasi pada kepentingan politik atau penguasa maka kepentingan rakyat untuk mendapat perlindungan akan terabaikan. Perlindungan tenaga kerja termasuk perlindungan atas hak-hak dasar pekerja untuk berorganisasi dan berunding dengan pengusaha, perlindungan keselamatan dan kesehatan kerja, perlindungan khusus tenaga 
wanita, anak, orang muda dan penyandang cacat serta perlindungan upah dan jaminan sosial tenaga kerja. Pelatihan kerja yang diarahkan untuk meningkatkan dan mengembangkan ketrampilan serta keahlian tenaga kerja guna meningkatkan produktivitas perusahaan. Penyelenggaraan perlindungan, pemiliharaan dan peningkatan kesejahteraan merupakan salah satu tanggung jawab dan kewajiban negara untuk memberikan perlindungan sosial ekonomi kepada masyarakat. Namun cakupan perlindungan yang dimaksudkan dalam UU No. 13 tahun 2003 tentang Ketenagakerjaan sulit untuk diterapkan untuk persoalan-persoalan yang dihadapi oleh tenaga kerja Indonesia yang bekerja di luar negeri ${ }^{2}$.

Kondisi demikian menuntut perlunya langkah-langkah untuk mencapai sasaran progam penempatan TKI ke luar negeri. Untuk itu, kebijakan penempatan TKI harus matang dan sistematis meliputi keseluruhan proses perekrutan, pengurusan dokumen, pendidikan dan pelatihan, penampungan, persiapan pemberangkatan sampai ke negara tujuan, dan pemulangan dari negara tujuan, hingga advokasi bila terjadi permasalahan. Hal ini harus ditempuh pemerintah karena pengiriman TKI hakekatnya bukan hanya persoalan mempertemukan kebutuhan para TKI dan majikan dari luar negeri seperti yang dipikirkan para ekonom, namun juga terkait perbaikan harkat dan martabat para TKI dan keluarganya.

Dalam upaya meningkatan kualitas penempatan dan keamanan perlindungan TKI telah dibentuk Badan Nasional Penempatan dan Perlindungan Tenaga Kerja Indonesia (BNP2TKI). Kemudian disusul dengan lahirnya Peraturan Presiden (Perpres) No 81 Tahun 2006 tentang Pembentukan BNP2TKI yang struktur operasional kerjanya melibatkan unsur-unsur instansi pemerintah pusat terkait pelayanan TKI, antara lain Kemenlu, Kemenhub, Kemenakertrans, Kepolisian, Kemensos, Kemendiknas, Kemenkes, Imigrasi (Kemenhukam), Sesneg, dan lain-lain. Dengan adanya BNP2TKI ini, maka segala urusan kegiatan penempatan dan perlindungan TKI berada dalam otoritas BNP2TKI, yang dikoordinasi Menteri Tenaga Kerja dan Transmigrasi.

\section{B. Pembahasan}

\section{Penempatan Tenaga Kerja Indonesia di Luar Negeri Tenaga Kerja Indonesia}

Penempatan Tenaga Kerja Indonesia ke Luar Negeri diatur dalam Peraturan Menteri Ketenagakerjaan Republik Indonesia Tahun 2014 tentang Pelaksanaan Penempatan dan Perlindungan Tenaga Kerja Indonesia di Luar Negeri. Undang-Undang

\footnotetext{
${ }^{2}$ Agusmidah, 2010, Hukum Ketenagakerjaan Indonesia, Ghalia Indonesia, Bogor, 2010, hlm. 103.
} 
ini mengatur prosedural dan tata cara penempatan TKI ke luar negeri. Pasal 1 angka 2 Permennaker No. 22 Tahun 2014 menyebutkan bahwa tenaga kerja Indonesia adalah setiap warga negara Indonesia yang memenuhi syarat untuk bekerja di luar negeri dalam hubungan kerja untuk jangka waktu tertentu dengan menerima upah. Pengertian tenaga kerja menurut Soepomo adalah semua orang yang mampu dan dibolehkan melakukan pekerjaan, baik yang sudah mempunyai pekerjaan, dalam hubungan kerja atau sebagai swasta pekerja maupun yang belum atau tidak mempunyai pekerjaan.

Dalam pengertian ini cakupan mengenai tenaga kerja lebih luas lagi yaitu meliputi tenaga kerja yang bekerja di dalam maupun di luar hubungan kerja yang belum mempunyai pekerjaan (pengangguran) ${ }^{3}$. Menurut Undang-Undang No. 13 tahun 2003 tentang ketenagakerjaan Bab I pasal 1 angka 2, tenaga kerja adalah setiap orang yang mampu melakukan pekerjaan guna menghasilkan barang dan/atau jasa baik untuk memenuhi kebutuhan sendiri maupun untuk masyarakat. Manulang memberikan pengertian tentang tenaga kerja yang meliputi angkatan kerja dan bukan angkatan kerja. Angkatan kerja terdiri dari golongan yang bekerja dan golongan yang mengganggur atau sedang mencari pekerjaan. Kelompok bukan angkatan kerja terdiri dari golongan yang bersekolah, yang mengurus rumah tangga dan golonggan lain-lain atau penerima pendapatan ${ }^{4}$.

TKI perempuan seringkali disebut Tenaga Kerja Wanita (TKW). Berdasarkan Keputusan Menteri Tenaga Kerja Nomor: Kep-138/Men/2000 tentang Penempatan Tenaga Kerja ke Luar Negeri Berkaitan dengan TKI. Faktor-faktor yang menyebabkan meningkatnya migrasi, khususnya perempuan, ke luar negeri adalah ${ }^{5}$ :

1. Perkembangan ekonomi yang sangat pesat di negara-negara tujuan dan meningkatnya permintaan terhadap buruh migran perempuan;

2. Kebijakan migrasi tenaga kerja resmi dari pemerintah, maka perekrutan perempuan secara aktif digalakkan melalui kerjasama agen perekrut tenaga kerja;

3. Stereotip jender terhadap perempuan dalam situasi kerja mencerminkan peran tradisional mereka sebagai pengasuh dan penghibur;

\footnotetext{
${ }^{3}$ Iman Soepomo, Pengantar Hukum Perburuhan, Jakarta, Djambatan, 1992, hlm 27.

${ }^{4}$ Senjun H. Manulang, Ketentuan Pokok-pokok Hukum Ketenagakerjaan, Jakarta, Rieeka Cipta, 1990, hlm $3 .$.

${ }^{5}$ Loso,"Aspek-Aspek Perlindungan Hukum Tenaga Kerja Indonesia (TKI) di Luar Negeri Berdasarkan UndangUndang No. 39 Tahun 2004 tentang Penempatan Tenaga Kerja di Luar Negeri”. Jurnal Ilmu Hukum Pandecta. Volume I No. 2. Semarang: Universitas Negeri Semarang. 2007, hlm. 173
} 
4. Meningkatnya kemiskinan dalam konteks program penyesuaian struktural (Structural Adjusment Programme) yang menyebabkan penduduk pedesaan kehilangan tanah dan menjadi semakin miskin;

5. Kurang kesempatan kerja dalam negeri yang memungkinkan perempuan untuk mencari pekerjaan yang lebih baik, meningkatkan keterampilan dan memperoleh masa depan yang lebih menjamin;

6. Meningkatnya ketergantungan keluarga pada perempuan untuk memperoleh pendapatan, khususnya dari keluarga tidak mampu.

Setiap wanita yang ingin menjadi tenaga kerja yang bekeja di luar negeri harus memenuhi persyaratan tertentu, yaitu :

a. usia minimal 18 tahun kecuali negara tujuan menentukan lain;

b. memiliki kartu tanda penduduk;

c. sehat mental dan fisik yang dibuktikan dengan surat keterangan dokter;

d. sekurang-kurangnya tamat SLTP, memiliki keterampilan atau keahlian atau pengalaman sesuai dengan persyaratan jabatan atau pekerjaan yang diperlukan;

e. izin dari orangtua atau wali bagi yang belum berkeluarga dan suami bagi yang sudah berkeluarga, dengan menyertakan foto kopi buku nikah.

\section{Sejarah Tenaga Kerja Indonesia}

Pemerintah Belanda pada tahun 1890 telah mengirimkan 32.986 orang TKI asal pulau Jawa ke Suriname yang merupakan negara jajahan Belanda di Amerika Selatan, jauh sebelum Pemerintah Republik Indonesia mengirimkan Tenaga Kerja Indonesia ke Luar Negeri. Tujuan pengiriman TKI itu adalah untuk mengganti tugas para budak asal Afrika yang telah dibebaskan pada tanggal 1 Juli 1863. Adapun dasar Pemerintah Belanda memilih para TKI dari pulau Jawa itu karena rendahnya tingkat perekonomian penduduk sebagai akibat bencana meletusnya gunung berapi dan padatnya penduduk di pulau Jawa jika dibandingkan dengan daerah lainnya. Berbagai cerita tentang meletusnya gunung berapi itu sering disampaikan para TKI pada saat itu kepada para anak cucunya di Suriname, karena mereka tahu betul, bahkan mengalami adanya udan awu atau hujan debu akibat letusan gunung berapi sebelum mereka diberangkatkan untuk kerja kontrak ke Suriname. Pada umumnya para TKI itu 
berasal dari daerah Jawa Tengah dan Jawa Timur. Ada juga dari daerah Jawa Barat tetapi jumlahnya lebih sedikit ${ }^{6}$.

Penduduk Indonesia pada zaman Perang Dunia II dijadikan Romusha untuk dijadikan pekerja dalam hal membangun jalan, jembatan, lapangan terbang, dan fasilitas umum maupun militer bagi pemerintah Jepang. Kebanyakan dari mereka dikirim ke Malaysia, Birma, Singapura, dan Thailand. Pada zaman setelah kemerdekaan, pengiriman TKI dimulai pada tahun 1969. TKI tersebut dikirim Belanda dan Jerman untuk bekerja sebagai perawat. Sejak saat itu jumlah permintaan akan TKI dari tahun ke tahun semakin bertambah. Pengiriman TKI seolah-olah menjadi jawaban atas permasalahan perekonomian yang dialami oleh kebanyakan rakyat Indonesia. Permintaan akan pekerja asal Indonesia di berbagai negara meningkat terutama untuk sektor informal, seperti menjadi pembantu rumah tangga atau menjadi buruh di perkebunan. Hal ini disebabkan jumlah sumber daya manusia untuk bidang-bidang tersebut sanngat terbatas jumlahnya dan juga upah pekerja asal Indonesia yang cukup murah. Indonesia sendiri melihat bidang ini sebagai jalan untuk menambah lapangan kerja serta upaya untuk meningkatkan kesejahteraan rakyatnya.

\section{Pengaturan Penempatan Tenaga Kerja Indonesia di Luar Negeri}

\section{Hak dan Kewajiban Tenaga Kerja Indonesia}

Hak dan kewajiban TKI diatur dalam Pasal 8 dan Pasal 9 Undang-Undang Republik Indonesia Nomor 39 Tahun 2004 Tentang Penempatan dan Perlindungan Tenaga Kerja Indonesia di Luar Negeri. Setiap calon TKI/ TKI mempunyai hak dan kesempatan yang sama untuk:

a. bekerja di luar negeri;

b. memperoleh informasi yang benar mengenai pasar kerja luar negeri dan prosedur penempatan TKI di luar negeri;

c. memperoleh pelayanan dan perlakuan yang sama dalam penempatan di luar negeri;

d. memperoleh kebebasan menganut agama dan keyakinannya serta kesempatan untuk menjalankan ibadah sesuai dengan agama dan keyakinan yang dianutnya;

e. memperoleh upah sesuai dengan standar upah yang berlaku di negara tujuan;

\footnotetext{
${ }^{6}$ Sandy Wahyudi. Peranan Kantor Perwakilan Indonesia di Luar Negeri dalam Melindungi Tenaga Kerja Wanita. Depok : Universitas Indonesia Fakultas Hukum, 2008, hlm. 31.
} 
f. memperoleh hak, kesempatan, dan perlakuan yang sama yang diperoleh tenaga kerja asing lainnya sesuai dengan peraturan perundang-undangan di negara tujuan;

g. memperoleh jaminan perlindungan hukum sesuai dengan peraturan perundang-undangan atas tindakan yang dapat merendahkan harkat dan martabatnya serta pelanggaran atas hak-hak yang ditetapkan sesuai dengan peraturan perundangundangan selama penampatan

h. di luar negeri;

i. memperoleh jaminan perlindungan keselamatan dan keamanan kepulangan TKI ke tempat asal;

j. memperoleh naskah perjanjian kerja yang asli.

k. Setiap calon TKI/ TKI mempunyai kewajiban untuk:

1. menaati peraturan perundang-undangan baik di dalam negeri maupun di negara tujuan;

m. menaati dan melaksanakan pekerjaannya sesuai dengan perjanjian kerja;

n. membayar biaya pelayanan penempatan TKI di luar negeri sesuai dengan peraturan perundang-undangan; dan

o. memberitahukan atau melaporkan kedatangan keberadaan dan kepulangan TKI kepada Perwakilan Republik Indonesia di negara tujuan.

\section{Tujuan dan Sasaran Pengiriman TKI}

Tujuan pengiriman TKI pada intinya adalah untuk ${ }^{7}$ :

1. Perluasan lapangan kerja.

2. Peningkatan kualitas tenaga kerja.

3. Peningkatan perlindungan tenaga kerja.

4. Peningkatan kesejahteraan tenaga kerja.

5. Peningkatan penerimaan devisa Negara.

Sedangkan, sasaran yang tercantum dalam Pasal 2 Keputusan Menteri Tenaga Kerja No. 204 Tahun 1999 adalah : " Penempatan TKI diselenggarakan secara tertib, efisien dan efektif untuk meningkatkan perlindungan, kesejahteraan tenaga

${ }^{7}$ Direktorat jasa TKI ke Luar Negeri, Pedoman Penempatan Tenaga Kerja ke Luar Negeri, Jakarta, Bina Penta, 1994, hlm.17. 
kerja, perluasan lapangan kerja, kualitas tenaga kerja, dan peningkatan penerimaan devisa dengan memperhatikan harkat dan martabat manusia, bangsa dan negara.

\section{Pihak-Pihak Yang Terlibat Dalam Pengiriman TKI}

Ada beberapa pihak yang terlibat dalam pengiriman TKI ke luar negeri yaitu:

a. Calon TKI

Calon TKI adalah setiap warga Negara Indonesia yang memenuhi syarat pencari kerja yang akan bekerja di luar negeri dan terdaftar di instansi pemerintah Kabupaten/Kota yang bertanggung jawab di bidang ketenagakerjaan.

b. Pelaksana Penempatan TKI, dalam hal ini adalah Badan Nasional Penempatan dan Perlindungan Tenaga Kerja Indonesia (BNP2TKI) yang berada di tingkat pusat, yang selanjutnya mengeluarkan surat ijin pengerahan yang disebarkan di setiap propinsi di seluruh Indonesia melalui Balai Pelayanan Penempatan dan Perlindungan Tenaga Kerja Indonesia (BP3TKI)

Tugas BP3TKI seperti yang diatur dalam pasal 22 UU No.39/2004 sebagai berikut:

1) Melakukan penyuluhan dan pendataan calon TKI.

2) Melakukan pendaftaran dan seleksi calon TKI.

3) Menyelesaikan kasus calon TKI atau TKI pada pra atau purna penempatan

4) Menandatangani Perjanjian penempatan dengan calon TKI atas nama pelaksana penempatan TKI.

Seluruh kegiatan yang dilakukan oleh BP3TKI di daerah menjadi tanggung jawab BNP2TKI di tingkat nasional.

c. Perwakilan pelaksanan penempatan TKI di luar negeri (PERWALU/ Perwakilan Luar Negeri)

Untuk mewakili kepentingan pelaksanaan penempatan TKI maka wajib mempunyai perwakilan di Negara TKI ditempatkan. Pelaksana penempatan TKI tersebut harus melaporkan keberadaan PERWALU kepada kepala perwakilan RI di Negara tujuan dan kepala Direktur Jendral Pembina Penempatan Tenaga kerja Depnakertrans dengan melampirkan : 
1) Nama dan alamat lengkap PERWALU

2) Surat keputusan Direksi tentang dasar pembentukan serta penanggung jawab PERWALU

3) Struktur organisasi, tugas dan fungsi PERWALU

Tugas PERWALU adalah:

1) Melakukan promosi dan pemasaran jasa TKI di luar negeri

2) Mencari lowongan pekerjaan

3) Menandatangani dokumen yang berkaitan dengan penempatan TKI

d. Mitra Usaha

Pelaksanan penempatan TKI ke luar negeri harus mempunyai mitra usaha. Mitra usaha adalah instansi atau badan usaha berbentuk hukum di Negara tujuan yang bertanggung jawab atas penempatan TKI pada pengguna. Mitra usaha seperti diatas harus memenuhi persyaratan yang diatur dalam Pasal 24 ayat (2) kepmenakertrans No. 22 Tahun 2014 tentang Penempatan Tenaga Kerja ke Luar Negeri yang berbunyi sebagai berikut ${ }^{8}$ :

1) Berbadan hukum dan memiliki izin usaha sebagai pelaksanaan penempatan TKI dari instansi berwenang sesuai dengan peraturan perundang-undangan Negara tujuan.

2) Mempunyai alamat dan penanggung jawab yang jelas

3) Mempunyai Perjanjian kerjasama penempatan.

4) Memiliki kinerja reputasi yang baik dibidang penempatan tenaga kerja.

e. Pengguna Jasa

Pengguna jasa adalah instansi Pemerintah, Badan Hukum Pemerintah, Badan Hukum Swasta dan atau perseorangan di Negara tujuan yang mempekerjakan TKI. Pengguna jasa seperti tersebut di atas harus memenuhi persyaratan yaitu :

1) Badan hukum atau perseorangan yang diizini mempekerjakan tenaga kerja asing dengan peraturan perundang-undangan Negara tujuan.

2) Mempunyai alamat yang jelas.

\section{Syarat-syarat Menjadi TKI}

Untuk menjadi calon TKI harus memenuhi persyaratan antara lain :

\footnotetext{
${ }^{8}$ Kepmenakertrans RI No. Kep-22 A/MEN/2014, Bandung, Nuansa Aulia, 2014. Hlm. 332.
} 
a. Berusia sekurang-kurangnya 18 tahun kecuali bagi calon TKI yang akan dipekerjakan pada pengguna peroragan sekurang-kurangnya berusia 21 tahun

b. Sehat jasmani dan rohani

c. Tidak dalam keadaan hamil bagi calon tenaga kerja perempuan

d. Berpendidikan sekurang-kurangnya lulus Sekolah Lanjutan Tingkat Pertama (SLTP) atau sederajat.

\section{Prosedur Penempatan TKI}

Penempatan TKI di luar negeri hanya dapat dilakukan ke Negara tujuan yang pemerintahnya telah membuat perjanjian tertulis dengan Pemerintah RI yang mempunyai peraturan perundang-undangan yang melindungi tenaga kerja asing. Kuota permintaan dari Negara pengguna jasa TKI tersebut harus mengajukan job order kepada yang berwenang dalam hal ini ditanggani oleh Badan Nasional Penempatan dan Perlindungan Tenaga Kerja Indonesia (BNP2TKI) yang berada di tingkat pusat, yang selanjutnya mengeluarkan surat ijin pengerahan yang disebarkan di setiap propinsi di seluruh Indonesia melalui Balai Pelayanan Penempatan dan Perlindungan Tenaga Kerja Indonesia (BP3TKI) dan bila setiap daerah telah terbagi menurut kebutuhan tenaga kerja, maka setiap daerah akan memperoleh informasi untuk mempersiapkan TKI yang memenuhi syarat untuk mendaftar, biasanya pengumuman ini dilaksanakan oleh Dinas Tenaga Kerja Daerah setempat dengan dibantu oleh pihak swasta dalam hal ini PPTKIS (Pelaksana Penempatan Tenaga Kerja Indonesia Swasta).

Dalam prosedur Penempatan TKI ke luar negeri terdapat kegiatan Pra Penempatan yang meliputi :

a. Pengurusan SIP

Untuk mendapat SIP, pelaksana penempatan TKI harus memiliki:

1) Perjanjian kerja sama penempatan ;

2) Surat permintaan TKI dari Pengguna ;

3) Rancangan perjanjian penempatan ;dan

4) Rancangan perjanjian kerja.

b. Rekruitmen

Proses perekrutan didahului dengan memberikan informasi kepada calon TKI sekurang-kurangnya tentang: Tata cara perekrutan ; Dokumen yang diperlukan ; Hak dan kewajiban calon TKI/TKI ; Situasi, kondisi, dan resiko di Negara tujuan ; dan Tata cara perlindungan bagi TKI. 
c. Pendidikan dan pelatihan kerja

Calon TKI berhak mendapat pendidikan dan pelatihan kerja sesuai dengan pekerjaan yang akan dilakukan, yaitu : Membekali, meningkatkan dan mengembangkan kompetensi kerja calon TKI ; Memberikan pengetahuan dan pemahaman tentang situasi, kondisi, adat istiadat, budaya, agama, dan resiko bekerja di luar negeri ; Membekali kemampuan berkomunikasi dalam bahasa Negara tujuan; Memberi pengetahuan dan pemahaman tentang hak dan kewajiban calon TKI/TKI.

d. Pemeriksaan kesehatan dan psikologi

Pemeriksaan kesehatan dan psikologi bagi calon TKI dimaksudkan untuk mengetahui derajat kesehatan dan tingkat kesiapan psikis serta kesesuaian kepribadian calon TKI dengan pekerjaan yang akan dilakukan di Negara tujuan. Setiap calon TKI harus mengikuti pemeriksaan kesehatan dan psikologi yang diselenggarakan oleh sarana kesehatan dan lembaga pemeriksaan psikologi yang ditunjuk pemerintah.

e. Uji kompetensi

Uji kompetensi ini bersifat mutlak dan apabila dinyatakan tidak lulus atau gagal maka pelaksana penempatan TKI dilarang memberangkatkan calon TKI yang bersangkutan, bahkan seleksi juga harus pada tingkat pematangan psikologis dan kesehatan agar dapat diketahui tingkat kesiapan mental dan fisik para TKI, sehingga diharapkan para TKI dapat menjalankan pekerjaan dengan stamina yang lebih kuat.

f. Pengurusan dokumen.

Untuk dapat diberangkatkan ke luar negeri, calon TKI harus memiliki dokumen yang meliputi: Kartu tanpa penduduk, ijazah pendidikan terahir, akte kelahiran, atau surat keterangan kenal lahir; Surat keterangan status perkawinan, bagi yang telah menikah melampirkan copy buku nikah; Surat keterangan izin suami atau istri, izin orang tua, atau izin wali; Sertifikat kompetensi kerja; Surat keterangan sehat berdasarkan hasil pemeriksaan kesehatan dan psikologi; Paspor yang diterbitkan oleh Kantor Imigrasi setempat; Visa kerja; Perjanjian penempatan TKI; Perjanjian kerja; dan KTLN (Kartu Tanda Luar Negeri) 
g. Pembekalan Akhir Pemberangkatan (PAP).

Seperti yang diatur dalam Pasal 36 kepmenakertrans No. 22 Tahun 2004.PAP diadakan dengan maksud untuk memberikan pemahaman dan pendalaman terhadap: a. peraturan perundang-undangan di negara penempatan, yang meliputi materi: peraturan keimigrasian; peraturan ketenagakerjaan;dan peraturan yang berkaitan dengan ketentuan pidana di negara penempatan; b. materi perjanjian kerja, yang meliputi: jenis pekerjaan; hak dan kewajiban TKI dan pengguna; upah, waktu kerja, waktu istirahat/cuti, asuransi TKI; jangka waktu perjanjian kerja dan tata cara perpanjangan perjanjian kerja;dan cara penyelesaian masalah/perselisihan; c. materi lain yang dianggap perlu.

h. Prosedur Pemberangkatan

Palaksana penempatan TKI wajib memberangkatkan TKI ke luar negeri yang telah memenuhi persyaratan kelengkapan dokumen dan calon TKI yang bersangkutan terpilih dalam perekrutan. Perjanjian penempatan TKI tersebut sekurang-kurangnya harus memuat antara lain : Nama dan alamat Pelaksana Penempatan TKI; Nama, jenis kelamin, umur, status perkawinan, dan alamat calon TKI; Nama dan alamat calon pengguna; Hak dan kewajiban para pihak dalam rangka penempatan TKI di luar negeri yang harus sesuai dengan kesepakatan dan syarat-syarat yang ditentukan oleh calon pengguna tercantum dalam perjanjian kerjasama penempatan; Jabatan dan jenis pekerjaan calon TKI sesuai permintaan pengguna; Jaminan pelaksana penempatan TKI kepada calon TKI, apabila pengguna tidak memenuhi kewajibannya kepada TKI sesuai Perjanjian kerja; Waktu keberngkatan calon TKI; Biaya penempatan yang harus ditanggung oleh calon TKI dan cara pembayarannya; Tanggung jawab pengurusan penyelesaian masalah; Akibat atas terjadinya pelanggaran perjanjian penempatan TKI oleh salah satu pihak; dan Tanda tangan para pihak dalam perjanjian penempatan TKI.

Ketentuan perjanjian penempatan tidak boleh bertentangan dengan peraturan Perundang-undangan. Syarat dalam Perjanjian penempatan TKI tersebut sekurang-kurangnya rangkap 2 (dua) dengan bea materai dan masing-masing pihak mendapat 1 (satu) perjanjian penempatan TKI yang mempunyai kekuatan hukum yang sama. Berdasarkan uraian di atas, maka 
secara singkat prosedur penempatan TKI di luar negeri meliputi:Calon TKI mencari informasi lowongan kerja luar negeri ke sumber informasi yakni : Depnakertrans, BP3TKI, Dinaskertrans, PPTKIS, media masa, internet, dll; Calon TKI mengikuti penyuluhan, pendaftaran dan mengikuti seleksi; Calon TKI yang lulus seleksi menandatangani perjanjian penempatan; Calon TKI mengikuti tes kesehatan, pelatihan kerja dan uji kompetensi, mengurus paspor dan mengikuti progam asuransi TKI; Calon TKI mengikuti PAP dan menandatangani perjanjian kerja; TKI mengurus rekomendasi bebas fiscal ke luar negeri ke BP3TKI; TKI berangkat ke luar negeri dengan membawa dokumen lengkap; Setelah sampai di Negara tujuan, TKI melaporkan diri ke Perwkilan RI atau KBRI; TKI bekerja sesuai dengan perjanjian kerja dan memilih ijin tinggal dan ijin kerja di Negara tujuan; TKI selesai kontrak, dapat melaporkan ke KBRI untuk kembali ke tanah air atau memperpanjang kontrak kerja; 11) TKI tiba di tanah air.

\section{Simpulan}

Prinsip Penempatan dan Perlindungan Tenaga Kerja Indonesia di Luar Negeri adalah dengan melakukan penempatan dan perlindungan Tenaga Kerja Indonesia di luar negeri yaitu a). Dokumen jati diri asli tetapi palsu disosialisaikan tentang pentingnya kebenaran tentang data jati diri karena hal ini sangat membantu dan memudahkan pengurusan berbagai macam masalah. Selain itu juga terus menerus dilakukan peninjauan ulang, mengevaluasi, dan mengawasi kelengkapan data-data diri para TKI. Hal yang paling penting dilakukan adalah sanksi dan tindakan tegas bagi mereka yang memiliki dokumen jati diri asli tetapi palsu. b). Sertifikat Pelatihan, Sertifikat Uji Kesehatan, Sertifikat Uji Kompetensi yang dipalsukan. Menghimbau agar pihak yang terkait tidak membantu meloloskan TKI yang tidak memenuhi syarat kelulusan dalam pelatihan, uji kesehatan, dan uji kompetensi untuk memperoleh sertifikan yang dipalsukan. c). Majikan yang tidak memenuhi perjanjian kerja/upah tidak dibayar. Menghadapi hal ini maka akan diajukan kepada pihak yang berwenang yang menangani hal ini sehingga masalah ini dapat terselesaikan dengan baik yaitu TKI menerima haknya untuk menerima pembayaran upah dari hasil kerja TKI dengan sejumlah uang yang besarannya telah ditentukan. d). Penganiayaan terhadap TKI dan pelecehan seksual serta proses pemulangan TKI yang menjadi objek pemerasan/pemerkosaan/ pembunuhan. Mengajukan kepada pihak yang berwenang yang menangani hal ini sehingga masalah ini dapat terselesaikan dengan baik. e). Kemampuan berbahasa yang tak memadai. Dengan 
mengikuti diklat secara rutin dan terus menerus maka masalah kemampuan berbahasa bukan menjadi kendala bagi TKI untuk bekerja di luar negeri. f). Kemampuan mengenal budaya negara yang akan dituju. Menghadapi hal ini maka TKI diberikan pemahaman dan wawasan yang luas tentang Negara tujuan. Hal ini dilakukan dengan berbagai cara yaitu dengan membaca dan memahami budaya dan kebiasaan dari negara tujuan bekerja, menanyakan tentang budaya dan kebiasaan Negara tujuan pada TKI yang telah pernah bekerja di Negara tujuan.

\section{Daftar Pustaka}

Abdurrahman, Muslan, Ketidakpatuhan TKI Sebuah Efek Diskriminasi Hukum. Malang, PT. Penerbit Universitas Muhammadiyah Malang, 2006.

Agusmidah, Hukum Ketenagakerjaan Indonesia, Ghalia Indonesia, Bogor, 2010.

Amirudin, Pengantar Metode Penelitian Hukum, Jakarta, Raja Grafindo Prasada, 2006.

Anonymous, Kamus Besar Bahasa Indonesia Edisi Ketiga. Jakarta, Balai Pustaka, 2007.

BP3TKI, Profil BP3TKI Jawa Tengah, Semarang, BP3TKI, 2015

Direktorat jasa TKI ke Luar Negeri, Pedoman Penempatan Tenaga Kerja ke Luar Negeri, Jakarta, Bina Penta, 1994.

Ekowati, Lilik, Metode Penelitian Kualitatif, Surakarta, Widya, 2005.

Husni, Lalu, Pengantar Hukum Ketenagakerjaan Indonesia, Jakarta, PT. raja Grafindo Persada, 2003.

Keputusan Menteri Tenaga Kerja Nomor 22 Tahun 2014 tentang Pelaksanaan Penempatan dan Perlindungan Tenaga Kerja Indonesia di Luar Negeri

Koentjaraningrat, Metode-metode Penelitian Masyarakat, Jakarta, Gramedia Pustaka Umum, 1991.

Kountur, Ronny, Metode Penelitian untuk Penulisan Skripsi dan Tesis, Jakarta, PPM, 2004.

Loso,"Aspek-Aspek Perlindungan Hukum Tenaga Kerja Indonesia (TKI) di Luar Negeri Berdasarkan Undang-Undang No. 39 Tahun 2004 tentang Penempatan Tenaga Kerja di Luar Negeri”. Jurnal Ilmu Hukum Pandecta. Volume I No. 2. Semarang: Universitas Negeri Semarang. 2007

Manulang, Senjun H., Ketentuan Pokok-pokok Hukum Ketenagakerjaan, Jakarta, Rineka Cipta, 1990.

Margono, S., Metodologi Penelitian Pendidikan, Jakarta, Rineka Cipta, 2004.

Mooleong, Lexy J., Metodologi Penelitian kualitatif (edisi revisi), Bandung, PT. Remaja Rosdakarya, 2008.

Muhammad, Abdulkadir, "Hukum dan Penelitian Hukum”, Bandung, Citra Aditya Bakti, 2004.

Nainggolan, A. Edison. Buku Saku Tenaga Kerja Indonesia. Tabloid Dunia Tenaga Kerja Indonesia, 2007.

Peraturan Presiden (Perpres) No 81 Tahun 2006 tentang Pembentukan BNP2TKI.

Rahardjo, Satjipto, Ilmu Hukum. Bandung, Citra Aditya Bakti, 2000.

Ramayulis, Metodologi Pendidikan Agama Islam, Jakarta, Kalam Mulia, 2004. 
Sanjana, Wina, Pembelajaran Dalam Implementasi Kurikulum Berbasis Kompetensi. Jakarta, Kenscana Premada Media Grup, 2006.

Soekanto, Soerjono, Pengantar Penelitian Hukum, Yogyakarta, UI Pers, 2007.

Soemitro, Ronny Hanitijo, Metodologi Penelitian Hukum dan Jurimetri, Jakarta, Ghalia Indonesia, 2001.

Soepomo, Iman, Pengantar Hukum Perburuhan, Jakarta, Djambatan, 1992.

Sugiyono, Metode Penelitian Kuantitatif, Kualitatif dan R\&D, Bandung, Alfabeta, 2009.

Sukmadinata, Nana Syaodih. Metode Penelitian Pendidikan. Bandung, Remaja Rosda Karya, 2005.

Tafsir, Ahmad, Metodologi Pengajaran Agama Islam, Bandung, Remaja Rosdakarya, 1996.

Undang- Undang No. 13 Tahun 2003 tentang Ketenagakerjaan

Undang-Undang Dasar 1945

Wahyudi, Sandy. Peranan Kantor Perwakilan Indonesia di Luar Negeri dalam Melindungi Tenaga Kerja Wanita. Depok : Universitas Indonesia Fakultas Hukum, 2008.

Wirartha, I Made, Metode Penelitian Sosial Ekonomi. Yogyakarta, Andi. Offset, 2006 